\title{
Research of Strength, Frost Resistance, Abrasion Resistance and Shrinkage of Steel Fiber Concrete for Rigid Highways and Airfields Pavement Repair
}

\author{
Željko Kos ${ }^{1, *(1)}$, Sergii Kroviakov ${ }^{2}(\mathbb{D})$, Vitalii Kryzhanovskyi ${ }^{2}(\mathbb{C})$ and Iryna Grynyova ${ }^{3}$ \\ 1 Department of Civil Engineering, University North, University Center Varaždin, Jurja Križanića 31b, \\ 42000 Varaždin, Croatia \\ 2 Department of Highways and Airfields, Odessa State Academy of Civil Engineering and Architecture, \\ Didrihsona Street 4, 65029 Odessa, Ukraine; skrovyakov@ukr.net (S.K.); vitolloscience@gmail.com (V.K.) \\ 3 Department of Architecture Structures, Odessa State Academy of Civil Engineering and Architecture, \\ Didrihsona Street 4, 65029 Odessa, Ukraine; irene.grinyova@gmail.com \\ * Correspondence: zeljko.kos@unin.hr; Tel.: +385-98757989
}

check for updates

Citation: Kos, Ž.; Kroviakov, S.; Kryzhanovskyi, V.; Grynyova, I. Research of Strength, Frost

Resistance, Abrasion Resistance and Shrinkage of Steel Fiber Concrete for Rigid Highways and Airfields Pavement Repair. Appl. Sci. 2022, 12, 1174. https://doi.org/10.3390/ app12031174

Academic Editors: Alexey Beskopylny, Anatoly Lavrentyev, Evgenii Shcherban and Sergei Stel'makh

Received: 21 December 2021

Accepted: 19 January 2022

Published: 23 January 2022

Publisher's Note: MDPI stays neutral with regard to jurisdictional claims in published maps and institutional affiliations.

Copyright: (c) 2022 by the authors. Licensee MDPI, Basel, Switzerland. This article is an open access article distributed under the terms and conditions of the Creative Commons Attribution (CC BY) license (https:/ / creativecommons.org/licenses/by/ $4.0 /)$.

\begin{abstract}
High-early strength fiber-reinforced concretes are effective materials for the full depth repair of rigid highway and airfield pavements. A comprehensive study was carried out on the influence of the amount of steel anchor fiber and hardening accelerator on properties that are important for repairing concrete. A two-factor experiment was carried out, in which the influence of the hardening accelerator and fiber dosages on the strength, frost resistance, wear resistance and shrinkage of repaired steel-fiber-reinforced concrete for rigid pavements was studied. The investigated concretes contained $400 \mathrm{~kg} / \mathrm{m}^{3}$ of cement and polycarboxylate plasticizer in the amount of $1.2 \%$ of the cement content. It has been established that the optimal concrete compositions are with the amount of Sika Rapid 3 hardening accelerator from 1 to $2 \%$ of the cement content and the steel fiber amount from 60 to $90 \mathrm{~kg} / \mathrm{m}^{3}$. Optimal fiber-reinforced concrete compositions have a reduced shrinkage during hardening, and at the age of 2 days they have a compressive strength of at least $55 \mathrm{MPa}$ and a flexural strength of at least $8.5 \mathrm{MPa}$. At the design age, the fiber-reinforced concrete compressive strength is $85-90 \mathrm{MPa}$, its flexural strength ranges from 15.5 to $17.5 \mathrm{MPa}$, it has a frost resistance of F200 and abrasion not higher than $0.24 \mathrm{~g} / \mathrm{cm}^{2}$. These properties ensure the high durability of the repair material.
\end{abstract}

Keywords: fiber-reinforced concrete; road pavement; hardening accelerator; repair; shrinkage; abrasion

\section{Introduction and Background}

Cement concrete pavements are a priority in the construction of highway and airfield pavements [1]. The minimum design flexural strength for rigid highway pavements according to [2] is in the range of 4-5 MPa, and the minimum concrete grade for airfield pavements is C 32/40 [3]. It is necessary to take into account the annual increase in traffic loads, the limit values of which often exceed the design requirements during the overhaul period. The proper operational condition of rigid highway and airfield pavements provides for the use of high-early strength repair concrete mixtures to increase their bearing capacity and maintain traffic safety [4,5]. The task of developing efficacious and durable concretes for rigid pavement repair is becoming more and more urgent.

Full depth repair technology is increasingly being used in the repair of cement concrete pavements. Flexural strength is the main parameter of road and airfield pavements. The usage of fast-hardening concretes makes it possible to reach values of flexural strength of 2.8-5.0 $\mathrm{MPa}$ and compressive strengths of 21-50 MPa after the first day of hardening [6,7]. To obtain concretes with high-early strength, contemporary superplasticizers are used, which make it possible to greatly diminish the $W / C$ of mixtures while keeping their 
workability, and concrete mixtures can also be moreover modified with hardening accelerators $[8,9]$. As a result, fast-hardening concretes are characterized by low $W / C(0.3$ and less) due to early and grade compressive strengths of more than 70-90 MPa and flexural strengths of more than $9 \mathrm{MPa}$ being achieved [10]. As is known [11], high-strength concretes are characterized by increased brittleness, which is particularly important in conditions of dynamic loads from transport. In addition, due to the large amount of cement in the mixture, shrinkage deformations increase, especially in the early ages of hardening [12].

To solve the above-described issues, concretes with fiber reinforcement have been widely used in highway engineering, in which different fiber types are used: steel, basalt, polypropylene and glass [12-15]. The usage of fiber permits increases in crack resistance and the most important parameters for rigid pavements-flexural strength and reduced abrasion [16]. At the same time, steel fiber is the most effectual for many types of structures.

Steel fiber concrete was first used as a repair material for rigid road pavement in the USA [17]. The flexural strength of steel-fiber-reinforced concrete reaches high values $>12 \mathrm{MPa}$. The above-described benefits of this material make it possible to use it as a repair material for rigid road pavements.

Quite a lot of research in recent years has been devoted to fiber-reinforced concrete for rigid pavement repair, including high-early strength concretes. In [18], concrete with a hardening accelerator and steel fiber in the amount of $37 \mathrm{~kg} / \mathrm{m}^{3}$ at the age of 1 month reached a flexural strength of $7.4 \mathrm{MPa}$ with a cement content of $465-490 \mathrm{~kg} / \mathrm{m}^{3}$, but the early strength was not analyzed. In [19], using an accelerator and steel fiber in the amount of $72 \mathrm{~kg} / \mathrm{m}^{3}$, a fiber-reinforced concrete was developed with a compressive strength of more than $40 \mathrm{MPa}$ and a flexural strength of more than $4 \mathrm{MPa}$ already after $6 \mathrm{~h}$ of hardening. However, it required the use of a large number of expensive binders: type III fast-setting cement $-320 \mathrm{~kg} / \mathrm{m}^{3}$ + aluminate cement $-280 \mathrm{~kg} / \mathrm{m}^{3}$. In [20], by using fiber with a length of $55 \mathrm{~mm}$ in the amount of $78.5 \mathrm{~kg} / \mathrm{m}^{3}$, the flexural strength after 28 days was $8.81 \mathrm{MPa}$. At the same time, a large amount of Type I cement was used- $462 \mathrm{~kg} / \mathrm{m}^{3}$ —as well as a silica fume modifier- $66 \mathrm{~kg} / \mathrm{m}^{3}$. In [21], using fast-setting cement in the amount of $400 \mathrm{~kg} / \mathrm{m}^{3}$, silica fume in the amount of $40 \mathrm{~kg} / \mathrm{m}^{3}$ and steel fiber $60 \mathrm{~mm}$ in length in the amount of up to $50 \mathrm{~kg} / \mathrm{m}^{3}$, concrete was obtained with a compressive strength at the age of 3 days of up to $56.8 \mathrm{MPa}$. The maximum flexural strength at 28 days was $7.29 \mathrm{MPa}$. Basalt stone is used as a coarse aggregate, which has a high natural strength, in contrast to the widespread crushed stone. It should be noted that the works [18-21] did not study shrinkage deformations, which can significantly affect the properties of the repair material in the pavement.

The authors [22] studied fiber-reinforced concrete with CEM II/A-S 42.5 cement in the amount of $360 \mathrm{~kg} / \mathrm{m}^{3}$ and silica fume in the amount of $40 \mathrm{~kg} / \mathrm{m}^{3}$. The amount of steel anchor fiber with fiber lengths of 16 and $30 \mathrm{~mm}$ was varied in the range of 0 to $50 \mathrm{~kg} / \mathrm{m}^{3}$. Steel-fiber-reinforced concretes with a strength of 90-100 MPa were obtained, however, there is no information on the effect of the composition on the early flexural strength. At the same time, it was found that an increase in the amount of fiber and its length have a positive effect on a decrease in shrinkage at different times of hardening. The positive effect of steel anchor fiber on the reduction of shrinkage deformations was also established in [23], but it is important to note that the studies were carried out with only one fiber dosage of $20 \mathrm{~kg} / \mathrm{m}^{3}$.

A large amount of experimental data $[24,25]$ confirms the importance of determining the threshold for the effectiveness of dispersed reinforcement and modifiers, the excess of the rational amount of which already negatively affects the physical and mechanical properties of fiber-reinforced concrete and their durability. For example, [26] shows the positive effect of steel fiber, the amount of which varied from $0-62 \mathrm{~kg} / \mathrm{m}^{3}$, on the frost resistance of concrete. Thus, fiber-reinforced concretes with steel fibers and modifiers have been widely studied. However, complex studies of the properties of fiber-reinforced concrete for the rigid road and airfield pavements repair, in particular when using full depth repair technology. There is also not enough research on the combined effect of 
anchor steel fiber and hardening accelerators on concrete properties for the rigid pavements repair. For such materials, an important indicator is early flexural strength, frost resistance, abrasion and shrinkage. Such is a motivation for the methodology presented in the paper.

\section{Materials and Methods}

For fiber concrete mixture preparation, CEM II/AS 42.5 Portland cement with Blaine specific surface of $280 \mathrm{~m}^{2} / \mathrm{kg}$ was used. Chemical and mineralogy composition of the binder are shown in Table 1. Fine and coarse aggregates' grain size compositions are presented in Table 2. Aggregates meet the requirements of the following standards: DSTU B V.2.7-75-98 [27], DSTU B V.2.7-32-95 [28], BS EN 12620:2013 [29], ASTM C 33/C33M18 [30]. Steel anchor fiber with diameter of $1 \mathrm{~mm}$ and length $50 \mathrm{~mm}$ was used as concrete reinforcement.

Table 1. Chemical and mineralogy composition of the CEM II/ AS 42.5.

\begin{tabular}{cc}
\hline Name of the Indicator & Value, $\%$ by Mass \\
\hline Tricalcium silicate, $\mathrm{C}_{3} \mathrm{~S}$ & 66.95 \\
Dicalcium silicate, $\mathrm{C}_{2} \mathrm{~S}$ & 13.15 \\
Tricalcium aluminate, $\mathrm{C}_{3} \mathrm{~A}$ & 7.42 \\
Tetracalcium aluminoferrite, $\mathrm{C}_{\$} \mathrm{AF}$ & 12.48 \\
Calcium oxide, $\mathrm{CaO}$ & 64.49 \\
Silicone oxide, $\mathrm{SiO}_{2}$ & 20.32 \\
Alumina oxide, $\mathrm{Al}_{2} \mathrm{O}_{3}$ & 5.28 \\
Ferric oxide (III), $\mathrm{Fe}_{2} \mathrm{O}_{3}$ & 4.05 \\
Magnesium oxide, $\mathrm{MgO}$ & 0.74 \\
Chlorine ion content, $\mathrm{Cl}$ & - \\
Insoluble residue, $\mathrm{IR}$ & 0.28 \\
Ignition lost, $\mathrm{IL}$ & 0.33 \\
\hline
\end{tabular}

Table 2. Comparison of fine and coarse aggregates' sieve analysis according to different building codes.

\begin{tabular}{|c|c|c|c|c|c|c|c|c|}
\hline \multirow{2}{*}{$\begin{array}{l}\text { Sieve Size, } \\
\text { mm }\end{array}$} & \multicolumn{2}{|c|}{$\%$ Passing by Weight } & \multirow{2}{*}{$\begin{array}{c}\text { DSTU B } \\
\text { V.2.7-75-98 } \\
\begin{array}{c}\text { Crushed } \\
\text { Breakstone }\end{array}\end{array}$} & \multirow{2}{*}{$\begin{array}{c}\text { DSTU B } \\
\text { V.2.7-32-95 } \\
\text { Sand }\end{array}$} & \multicolumn{2}{|c|}{ BS EN 12620:2013 } & \multicolumn{2}{|c|}{ ASTM C 33/C33M-18 } \\
\hline & $\begin{array}{l}\text { Crushed } \\
\text { Breakstone }\end{array}$ & Sand & & & $\begin{array}{l}\text { Crushed } \\
\text { Breakstone }\end{array}$ & Sand & $\begin{array}{c}\text { Crushed } \\
\text { Breakstone }\end{array}$ & Sand \\
\hline 20 & 100 & 100 & $\geq 90$ & - & $90-99$ & - & $90-100$ & - \\
\hline 10 & 54.7 & 100 & $20-70$ & - & - & - & $20-55$ & 100 \\
\hline 5 & 5.0 & 100 & $0-10$ & - & $0-15$ & 100 & $0-10$ & $95-100$ \\
\hline 2.5 & 0.8 & 97.0 & - & $80-100$ & $0-5$ & $85-99$ & $0-5$ & $80-100$ \\
\hline 1.25 & 0 & 83.5 & - & $55-95$ & - & - & - & $50-85$ \\
\hline 0.63 & 0 & 48.3 & - & $30-80$ & - & - & - & $25-60$ \\
\hline 0.315 & 0 & 28.6 & - & $20-50$ & - & - & - & $5-30$ \\
\hline 0.16 & 0 & 8.5 & - & $0-15$ & - & - & - & $0-10$ \\
\hline$<0.16$ & 0 & 0.5 & - & - & - & - & - & - \\
\hline
\end{tabular}

Passage by weight of the applied crushed breakstone is $54.7 \%$ on a $10 \mathrm{~mm}$ sieve and $5 \%$ on a $5 \mathrm{~mm}$ sieve. According to the building codes, that is within the permissible limits of the following building codes: BS EN 12620: 2013 (sieve $10 \mathrm{~mm}$ not regulated, passage by sieve $5 \mathrm{~mm}$ in the range of $0-15 \%$ ); ASTM C 33/ C33M-18 standart (10 mm sieve pass by weight in the range of $20-55 \%$, sieve $5 \mathrm{~mm}$, pass by weight in the range $0-10 \%$ ); standard DSTU B V.2.7-75-98 (10 mm sieve passage by weight in the range of $20-70 \%$, sieve $5 \mathrm{~mm}$, passage by weight in the range of $0-10 \%$ ).

To preserve the workability of concrete mixtures, MasterGlenium SKY 608 plasticizer was used in an amount of $1.2 \%$ of the cement content $\left(4.8 \mathrm{~kg} / \mathrm{m}^{3}\right)$. This percentage was determined as rational for repair concrete in preliminary studies [31,32].

For determining of concrete properties, 2 variable factors of concrete composition were chosen: 
$X_{1}$-amount of the hardening accelerator admixture Sika Rapid 3 from 0 to $2.4 \%$ of the cement mass (from 0 to $9.6 \mathrm{~kg} / \mathrm{m}^{3}$ );

$X_{2}$-amount of steel anchor fiber from 0 to $100 \mathrm{~kg} / \mathrm{m}^{3}$.

Using the optimal symmetric 9-point plan with natural values of variable factors, lower $(-1)$, middle $(0)$ and upper $(+1)$ limits of variation [33], test concrete mixtures were designed (Table 3$)$.

The maximum amounts of accelerator and fiber in the experiment were taken based on the recommendations of the manufacturers. Anchor fiber of this length was chosen as an effective dispersed reinforcement, taking into account the fact that with full depth repair technology, concreting is carried out to a depth of one-third of the entire thickness of a road slab.

Table 3. Mix composition contents and mechanical properties of concrete and fiber concrete.

\begin{tabular}{|c|c|c|c|c|c|c|c|c|c|c|c|c|c|c|}
\hline \multirow[b]{2}{*}{$\begin{array}{l}\text { No. of } \\
\text { Mixture }\end{array}$} & \multirow[b]{2}{*}{$\begin{array}{c}\qquad X_{1}, \\
\text { Hardening } \\
\text { Accelerator }\end{array}$} & \multirow[b]{2}{*}{$\begin{array}{l}X_{2} \\
\text { Steel } \\
\text { Fiber }\end{array}$} & \multicolumn{7}{|c|}{ Concrete and Fibrous Concrete Mixtures } & \multirow[b]{2}{*}{$\begin{array}{l}f_{\text {ck.cube } 2} \\
\text { (MPa) }\end{array}$} & \multirow[b]{2}{*}{$\begin{array}{l}f_{\text {ck.cube }} \\
\text { (MPa) }\end{array}$} & \multirow[b]{2}{*}{$\begin{array}{l}f_{c t k 2} \\
(\mathrm{MPa})\end{array}$} & \multirow[b]{2}{*}{$\begin{array}{c}f_{c t k} \\
\text { (MPa) }\end{array}$} & \multirow[b]{2}{*}{$\begin{array}{l}W / C \\
\text { Ratio }\end{array}$} \\
\hline & & & $\begin{array}{l}\text { Cement, } \\
\mathrm{kg} / \mathrm{m}^{3}\end{array}$ & $\begin{array}{l}\text { Sand, } \\
\mathrm{kg} / \mathrm{m}^{3}\end{array}$ & $\begin{array}{l}\text { Crushed } \\
\text { Stone, } \\
\left(\mathrm{kg} / \mathrm{m}^{3}\right)\end{array}$ & $\begin{array}{c}\text { SKY } \\
608, \\
\%\end{array}$ & $\begin{array}{c}\text { Sika } \\
\text { Rapid } \\
3, \% \\
\left(X_{1}\right)\end{array}$ & $\begin{array}{c}\text { Steel } \\
\text { Fiber } \\
\mathrm{kg} / \mathrm{m}^{3}, \\
\left(X_{2}\right)\end{array}$ & $\begin{array}{l}\text { Water, } \\
\mathrm{L} / \mathrm{m}^{3}\end{array}$ & & & & & \\
\hline 1 & -1 & -1 & \multirow{9}{*}{400} & 830 & 1190 & \multirow{9}{*}{1.2} & 0 & 0 & 127 & 46.5 & 85.5 & 5.6 & 9.0 & 0.318 \\
\hline 2 & 0 & -1 & & 828 & 1190 & & 1.2 & 0 & 126 & 51.8 & 76.2 & 5.8 & 7.2 & 0.316 \\
\hline 3 & +1 & -1 & & 825 & 1190 & & 2.4 & 0 & 123 & 56.4 & 72.8 & 6.0 & 6.9 & 0.307 \\
\hline 4 & -1 & 0 & & 788 & 1180 & & 0 & 50 & 133 & 49.2 & 90.7 & 8.2 & 16.1 & 0.332 \\
\hline 5 & 0 & 0 & & 786 & 1180 & & 1.2 & 50 & 131 & 53.7 & 85.3 & 8.4 & 15.5 & 0.328 \\
\hline 6 & +1 & 0 & & 782 & 1180 & & 2.4 & 50 & 130 & 59.1 & 83.1 & 8.7 & 14.9 & 0.325 \\
\hline 7 & -1 & +1 & & 752 & 1170 & & 0 & 100 & 138 & 52.6 & 92.5 & 8.6 & 16.8 & 0.344 \\
\hline 8 & 0 & +1 & & 750 & 1170 & & 1.2 & 100 & 135 & 55.9 & 87.1 & 8.9 & 15.7 & 0.337 \\
\hline 9 & +1 & +1 & & 745 & 1170 & & 2.4 & 100 & 132 & 61.5 & 84.7 & 9.2 & 15.2 & 0.331 \\
\hline
\end{tabular}

\section{Research Results and Analysis}

Composition No. 1 was elaborated on the basis of previous studies [31,34] and was applied as a starting point for further modification. For this composition, as can be seen from Table 3 , the $W / C=0.318$, the compressive strength at the age of 2 days was $f_{\text {ck.cube } 2}=46.5 \mathrm{MPa}$, the compressive strength at the age of 28 days was $f_{\text {ck.cube }}=85.5 \mathrm{MPa}$, the flexural strength at the age of 2 days was $f_{c t k 2}=5.6 \mathrm{MPa}$ and the flexural strength at the age of 28 days was $f_{c t k}=9.0 \mathrm{MPa}$. In the rest of the mixtures, the cement content was kept the same as for the control mixture No. $1\left(400 \mathrm{~kg} / \mathrm{m}^{3}\right)$ in order to be able to correctly determine the effect of the fiber and the hardening accelerator.

All concrete mixtures had equal workability (slump 5-8 cm), determined according to the BS EN 12350-2:2019 [35] and the W/C ratio depended on the composition. Such workability was taken as typical for full depth repair mixtures. With a fixed $W / C$ ratio, it would be impossible to ensure the equal workability of the mixture, which is important during repairs, or it would be necessary to change the amount of plasticizer and would not allow us to provide its optimal amount. The amount of water changed in the mixture, and the amount of sand and gravel was selected depending on the amount of water, fiber and hardening accelerator. The fiber was introduced into the mixer after the supply of crushed breakstone and sand but before the supply of cement and water with admixtures. This ensured the homogenous distribution of the fibers.

According to the data in Table 3, to determine the influence effect of the steel fiber and the hardening accelerator dosages on the concrete's properties, an experimental statistical model (ES-model) was accepted (1). In the ES-model (1), the experimental error is 0.0013. The coefficients of all ES-models were calculated taking into account the accepted experimental error at 10\% two-sided risk. For a given risk level, after each calculation, the hypothesis was tested about the difference between the estimates of the ES-model coefficients from zero, i.e., the significance of the coefficients. To test the hypothesis about the equality of the coefficients to zero, the Gaussian accuracy criterion was used. The coefficients which, according to the results of the check, did not differ from zero were excluded from the ES-model. After eliminating insignificant coefficients, the model was recalculated, 
and the test was repeated. The ES-model with all significant coefficient estimates was tested for adequacy using the Fisher criterion [33]. Recording the polynomials of the ES-models in place of the reduced insignificant elements, a coefficient equal to zero was written, that is, the value \pm 0 was indicated:

$$
W / C=0.328-0.005 x_{1} \pm 0 x_{1}^{2} \pm 0 x_{1} x_{2}+0.012 x_{2}-0.003 x_{2}^{2} \pm 0 x_{1} x_{2}
$$

According to (1), a diagram was drawn, shown in Figure 1.

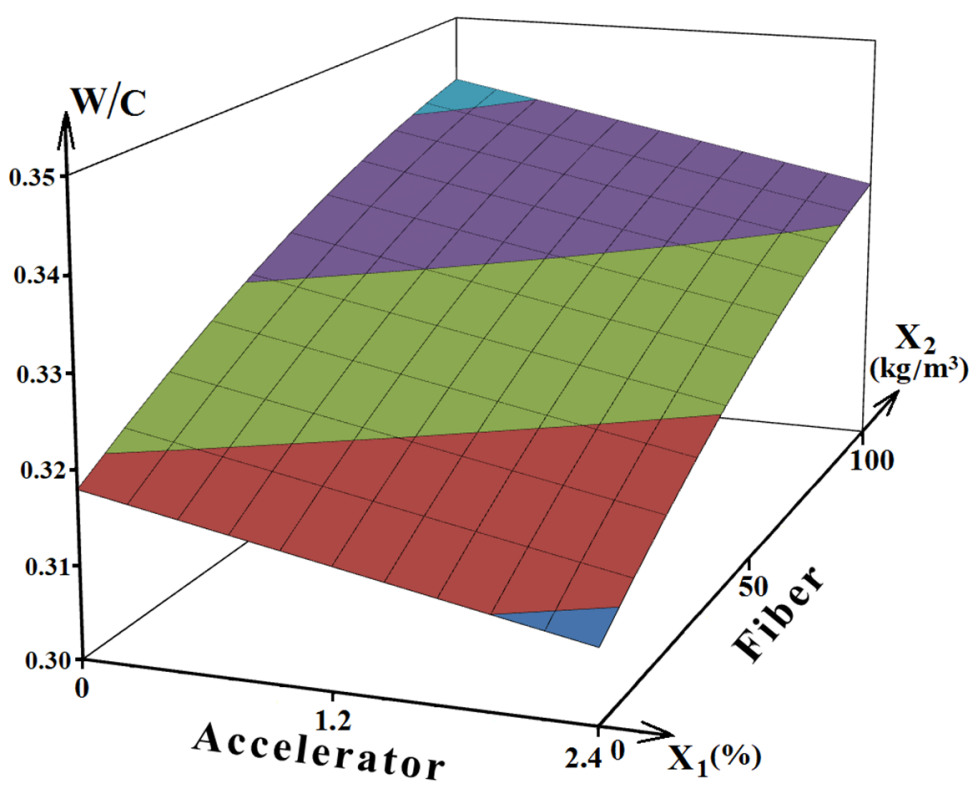

Figure 1. Variation of concrete and fiber-reinforced concrete mixtures $W / C$ depending on variable composition factors.

An analysis of the diagram in Figure 1 reflects that even with the maximum dosage of fiber $\left(100 \mathrm{~kg} / \mathrm{m}^{3}\right)$, the $W / C$ of mixtures are in the range of 0.332 to 0.344 . It is at such values of the $W / C$ ratio that it is possible to achieve a high-early strength of steel-fiberreinforced concrete, which is especially important for road repair. The amount of fiber has a nonlinear effect on the water demand of the mixtures and with the addition of dispersed reinforcement in the amount of $50 \mathrm{~kg} / \mathrm{m}^{3} \mathrm{~W} / \mathrm{C}$ ratio increases more visibly than with an increase in the fiber dosage from 50 to $100 \mathrm{~kg} / \mathrm{m}^{3}$. The volume of the hardening accelerator Sika Rapid 3 does not significantly affect the $W / C$ ratio of mixtures of equal workability, while the introduction of this modifier does not significantly reduce the $W / C$. In general, due to the use of the effective polycarboxylate type superplasticizer MasterGlenium SKY 608 , the $W / C$ ratios of all investigated concrete and fiber-reinforced concrete mixtures were in the range of 0.307 to 0.344 , which makes it achievable to provide high physical and mechanical properties and durability of concrete and fiber-reinforced concrete for the rigid pavements repair.

For each concrete and fiber-reinforced concrete composition, compressive strength tests were performed for samples at the age of 2 and 28 days (cubes $10 \mathrm{~cm} \times 10 \mathrm{~cm} \times 10 \mathrm{~cm}$ ) and flexural strength (prisms $10 \mathrm{~cm} \times 10 \mathrm{~cm} \times 40 \mathrm{~cm}$ ). The size of the samples was taken based on the size of the aggregates and the length of the fibers in accordance with the building codes ASTM C78/C78M-16 [36], DSTU B V.2.7-214:2009 [37], BS EN 12390-5:2009 [38] and BS EN 12390-3:2009 [39]. The strength tests of the concrete and fiber-reinforced concrete were carried out according to the same standards. To determine the strength at each experimental point at the age of 2 and 28 days, 3 cubes and 3 prisms were tested.

Figure 2 represents a scheme of the flexural strength tests of prism specimens, and Figures 3 and 4 represent steel-fiber-reinforced specimens after strength tests. 

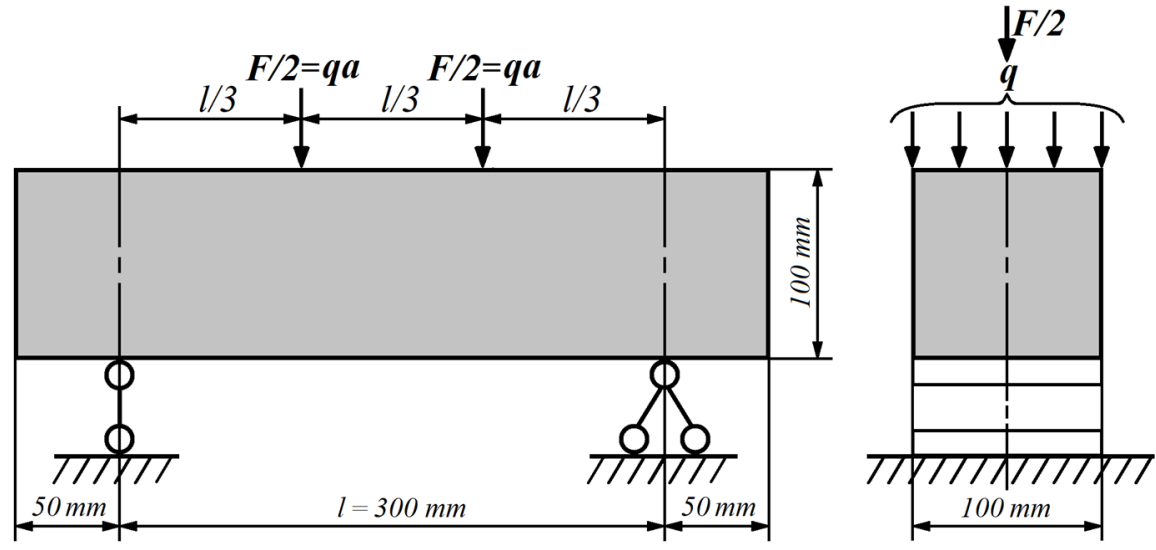

Figure 2. Load application scheme for flexural strength test according to standards ASTM C78/C78M16, DSTU B V.2.7-214:2009 and BS EN 12390-5:2009.

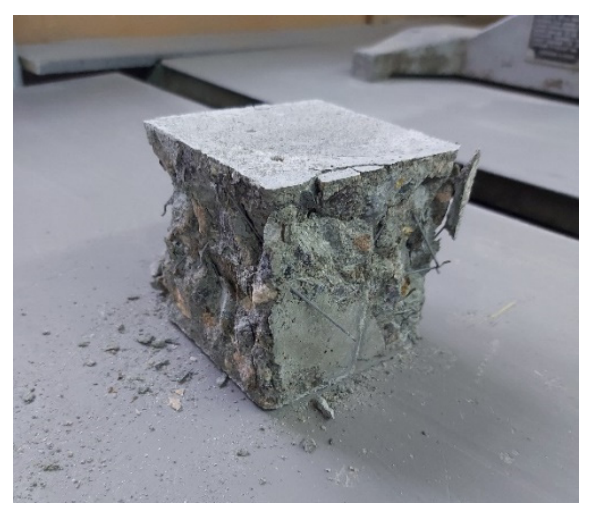

Figure 3. Steel-fiber-reinforced concrete specimen after compression strength test.

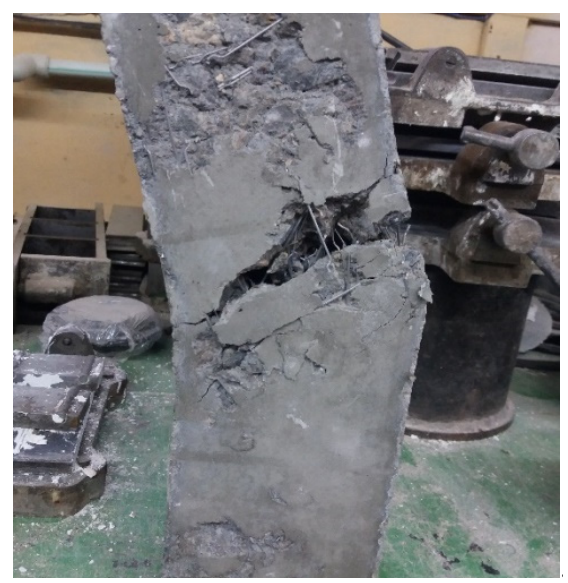

Figure 4. Steel-fiber-reinforced concrete specimen after flexural strength test.

As previously described, for highways and airfield pavements, flexural strength is one of the most important indicator of concrete quality. According to the variable composition factors (Table 3), ES-models (2) and (3) were calculated. Based on Equations (2) and (3), diagrams of the influence of repair composition concrete and fiber concrete factors on the flexural strength at the age of 2 days (Figure 5a) and 28 days (Figure 5b) were drawn. For the ES-model (2), the experimental error is $0.012 \mathrm{MPa}$, and for the ES-model (3), it is $0.204 \mathrm{MPa}$ :

$$
\begin{gathered}
f_{c t k 2}(\mathrm{MPa})=8.42+0.26 x_{1}+0.02 x_{1}{ }^{2}+1.55 x_{2}-1.08 x_{2}{ }^{2}+0.05 x_{1} x_{2}, \\
f_{c t k}(\mathrm{MPa})=15.27-0.81 x_{1}+0.35 x_{1}{ }^{2}+4.10 x_{2}-3.70 x_{2}{ }^{2} \pm 0 x_{1} x_{2}
\end{gathered}
$$




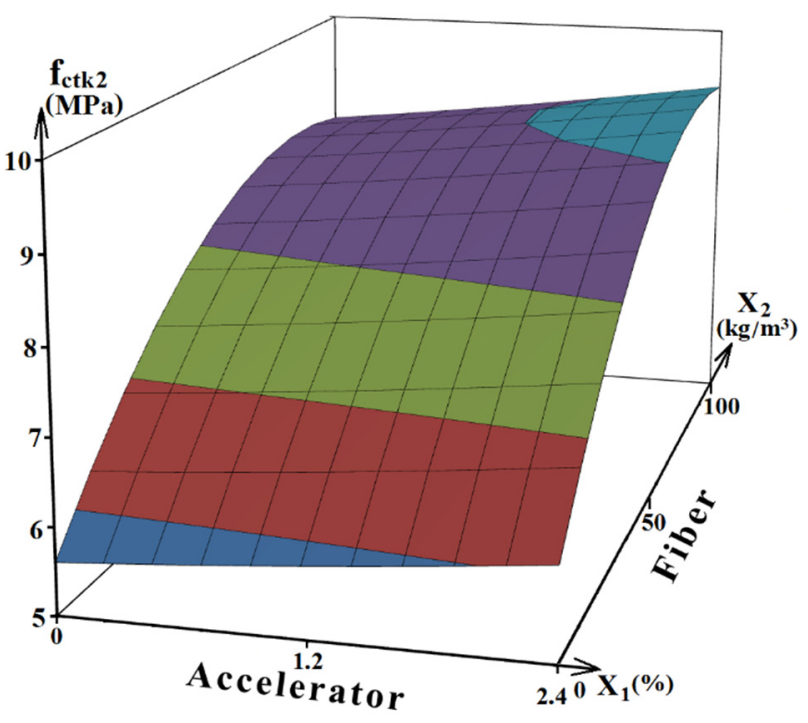

(a)

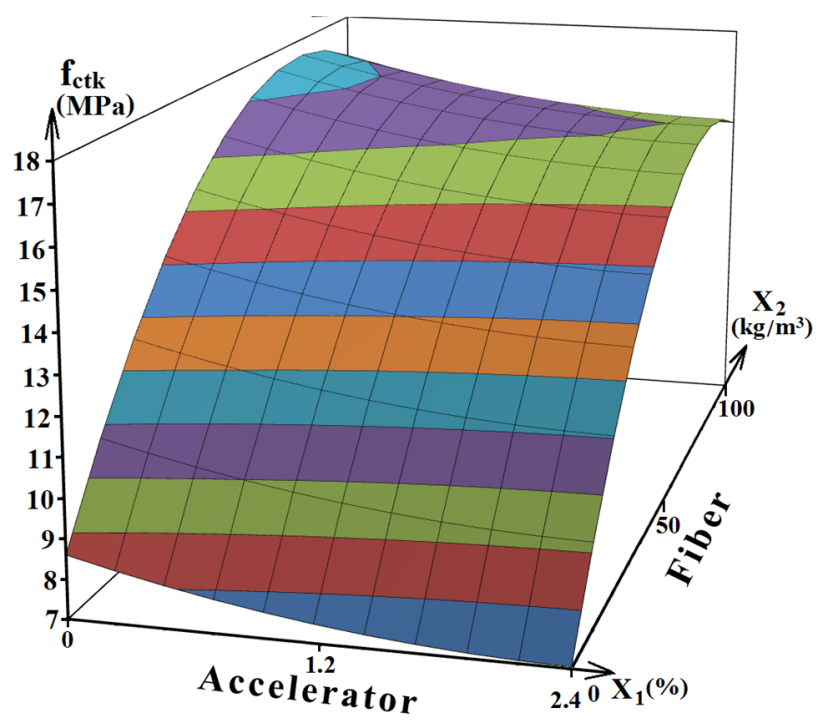

(b)

Figure 5. The combined effect of varied composition factors on the flexural strength of concretes and fiber-reinforced concretes at the age of 2 days (a) and 28 days (b).

An analysis of the diagram in Figure 5a shows that with a volume of the Sika Rapid hardening accelerator from $1.2 \%$ and with a steel fiber dosage from $60 \mathrm{~kg} / \mathrm{m}^{3}$ and higher, the early flexural strength of the repair concrete ( 2 days age) is at least 8.5 MPa. This level of concrete flexural strength allows the highway pavement to be operational. The values of the flexural strength of the investigated concretes and fiber-reinforced concretes at the age of 2 days are most influenced by the amount of steel anchor fiber. The highest $f_{c t k 2}$ value reaches 8.7-9.3 $\mathrm{MPa}$ with a fiber dosage in the range of $85-90 \mathrm{~kg} / \mathrm{m}^{3}$, and a further increase in the amount of fibers already negatively effects on the early flexural strength.

At the design age of 28 days, due to dispersed reinforcement with anchor steel fiber in the amount of 70-90 kg/m 3 , the concrete flexural strength increases more than 2 times: from 7-8.5 MPa up to 15.5-17.5 MPa (Figure 5b). The high efficiency of fiber reinforcement at the age of 28 days is explained due to the increase in concrete strength over time and the growth of the fiber adhesion strength to a cement-sand matrix [40]. Using anchor steel fiber in a dosage of more than $60 \mathrm{~kg} / \mathrm{m}^{3}$, the flexural strength of the fiber-reinforced concrete is not less than $16 \mathrm{MPa}$, which ensures the high-quality function of the material as a road pavement under the highest loads. Nevertheless, at the design age, when a hardening accelerator is added to the concrete composition, the flexural strength decreases slightly. This reduction is limited to $10-12 \%$ of the composition's strength without hardening accelerator with the same amount of fiber. It is important to note that the positive effect of fiber on strength is achieved despite the increase in the $W / C$ ratio required to maintain the workability of the mixture when dispersed reinforcement is introduced.

In addition, according to the data given in Table 3, ES-models (4) and (5) were calculated, reflecting the action of the hardening accelerator and fiber amount on the compressive strength of the investigated repair concrete and fiber-reinforced concrete at the ages of 2 and 28 days. For the ES-model (4), the experimental error is $0.301 \mathrm{MPa}$, and for the ES-model (5), it is $0.642 \mathrm{MPa}$ :

$$
\begin{aligned}
& f_{\text {ck.cube } 2}(\mathrm{MPa})=53.80+4.78 x_{1}+0.42 x_{1}{ }^{2}+2.55 x_{2} \pm 0 x_{2}{ }^{2}-0.25 x_{1} x_{2}, \\
& f_{\text {ck.cube }}(\mathrm{MPa})=85.02-4.68 x_{1}+2.02 x_{1}{ }^{2}+4.97 x_{2}-3.23 x_{2}{ }^{2}+1.23 x_{1} x_{2},
\end{aligned}
$$

The ES-models (4) and (5) were used to draw the diagrams shown in Figure 6.

The examination of the diagram in Figure 6a allows us to enclose that the amount of the hardening accelerator most significantly effects the early compressive strength of 
concrete and fiber-reinforced concrete for rigid pavement repair. With the addition of Sika Rapid 3 admixture in the amount of $2.4 \%$ by cement mass, the $f_{\text {ck.cube } 2}$ value increases by more than $9 \mathrm{MPa}$. Steel fiber also provides positive effects on the early compressive strength, despite the fibers' effect on the $W / C$ mixture.

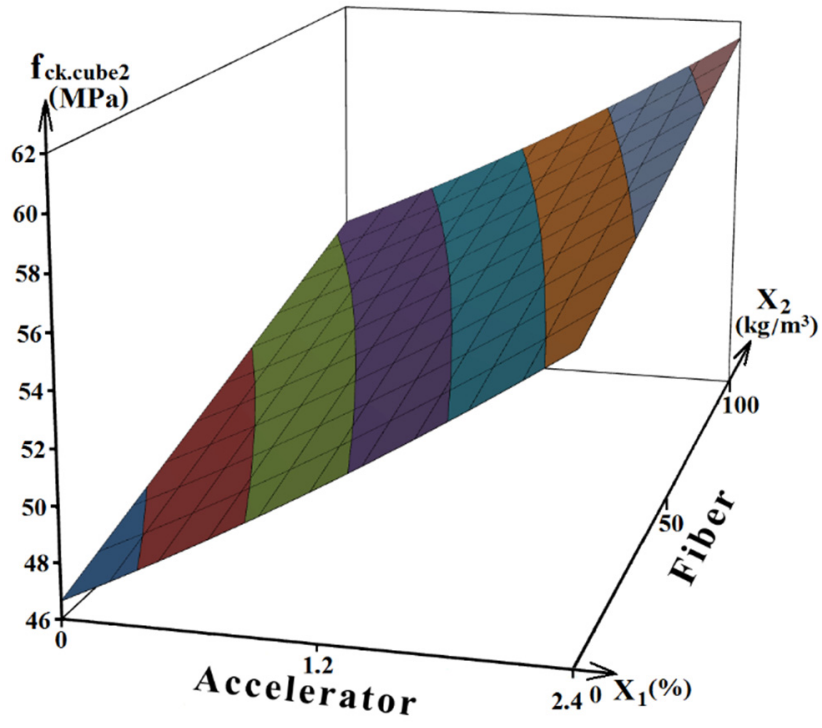

(a)

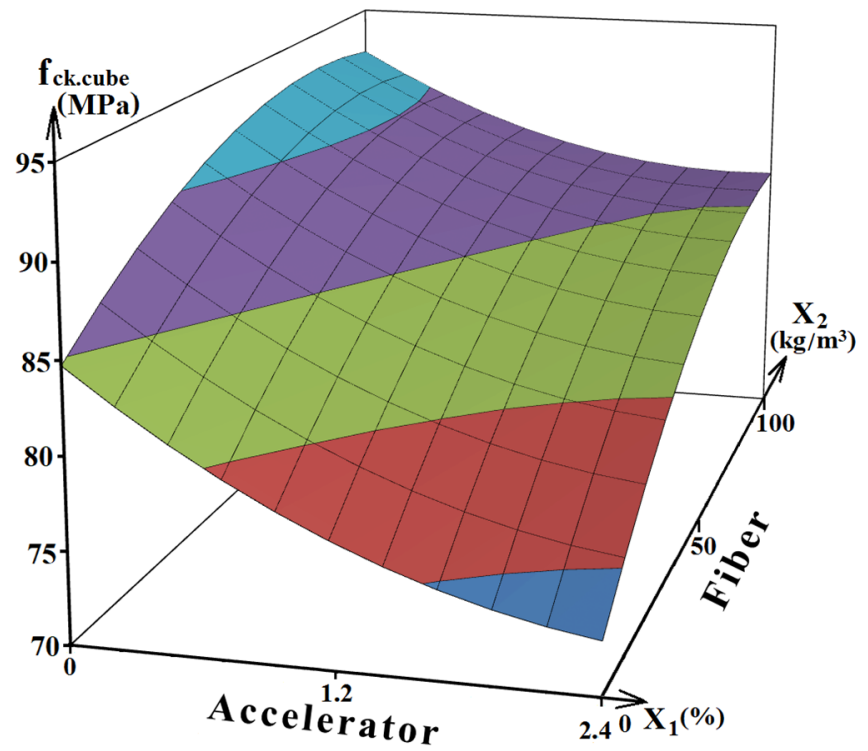

(b)

Figure 6. Change in the concrete and fiber-reinforced concrete compressive strengths with usage of varied factors: at the age of 2 days (a) and 28 days (b).

With the maximum amount of hardening accelerator, regardless of the fiber amount, the concrete has a compressive strength at the age of 2 days of at least $55 \mathrm{MPa}$ (grade C32/40). It allows us to begin the operation of the reconstructed highway section. At the same time, fiber-reinforced concretes with fiber amount in a composition of $50 \mathrm{~kg} / \mathrm{m}^{3}$ and more have a strength of $55 \mathrm{MPa}$ and more already with an amount of hardening accelerator from $1.4 \%$. Using the maximum amount of dispersed reinforcement and Sika Rapid 3 admixture, the early strength ( 2 days) of fiber-reinforced concrete is at least $60 \mathrm{MPa}$ (grade C 35/45).

At the design age, concretes and fiber-reinforced concretes containing the hardening accelerator have lower compressive strength than concretes of analogous compositions without the addition of Sika Rapid 3 (Figure $6 \mathrm{~b}$ ). Using an average amount of accelerator (1.2\% of the cement mass), the compressive strength of the investigated concretes decrease on average by $6 \mathrm{MPa}$. When using the maximum amount (2.4\% of the cement mass), they decrease by $9 \mathrm{MPa}$. This effect is known in concrete technology [41], but the main purpose of using the hardening accelerator is to achieve a high-early strength of repair concrete.

At the design age, the positive effect of dispersed steel fiber reinforcement on compressive strength is more palpable than at the age of 2 days. So, when using fiber in the amount of $50 \mathrm{~kg} / \mathrm{m}^{3}$, the concrete compressive strength increases by an average of $8 \mathrm{MPa}$, and when using the maximum amount of fiber, that is, $100 \mathrm{~kg} / \mathrm{m}^{3}$, the strength increases by an average of $10 \mathrm{MPa}$.

In general, the study of the modified fiber concrete's strength showed that by using a rational amount of the hardening accelerator Sika Rapid 3 and steel anchor fiber $\left(70-90 \mathrm{~kg} / \mathrm{m}^{3}\right)$, the received repair concrete materials are characterized by high compressive and flexural strengths at an early age and at the age of 28 days.

Frost resistance is an important durability indicator of cement-concrete roads and airfield pavements. During the experiment, frost resistance was measured by the accelerated method according to DSTU B V.2.7-49-96 [42] (the third method, freezing and thawing in salt water). The frost resistance grade is taken according to the number of cycles of 
alternating freezing-thawing, after which the strength loss of the main samples in comparison with the strength of the control samples was no more than $5 \%$, and the mass loss was no more than $3 \%$. The results of determining the loss of strength and mass of the investigated concrete and fiber-reinforced concrete specimens (in comparison with the control specimens) after 10,15 and 20 freezing cycles up to $-50 \pm 5{ }^{\circ} \mathrm{C}$ and thawing in $5 \%$ sodium chloride solution are shown in Table 4.

Analysis of the data given in the table allows us to conclude that all compositions with steel fiber (No. 4-9) have frost resistance F200, which ensures their high durability in climatic conditions typical for most European countries. Concrete composition No. 1 (without fiber and hardening accelerator) is also characterized by frost resistance at the level of F200. With the introduction of the hardening accelerator in the absence of dispersed reinforcement (concrete of compositions No. 2 and No. 3), the frost resistance of the material decreases to the level of F150. The fact of a decrease in the frost resistance of concretes without dispersed reinforcement with the hardening accelerator Sika Rapid 3 indicates a limited negative effect of the modifier on this indicator. The decrease in frost resistance can be explained by a general decrease in the strength of the composite at the design age when using the hardening modifier. The use of steel fiber in general contributes to an increase in the frost resistance of concretes for rigid pavement repair. This is confirmed by the fact that fiber-reinforced concretes, regardless of the amount of hardening accelerator, have frost resistances at the level of F200.

Table 4. Determination of concrete frost resistance according to DSTU B V.2.7-49-96 "Concrete. Accelerated methods for determining frost resistance with repeated freezing and thawing" (third method).

\begin{tabular}{|c|c|c|c|c|c|c|c|c|c|}
\hline \multirow[t]{2}{*}{$\begin{array}{l}\text { No. of } \\
\text { Mixture }\end{array}$} & \multirow{2}{*}{$\begin{array}{l}\quad X_{1}, \\
\text { Hardening } \\
\text { Accelerator }\end{array}$} & \multirow{2}{*}{$\begin{array}{l}X_{2} \\
\text { Steel } \\
\text { Fiber }\end{array}$} & \multicolumn{3}{|c|}{$\begin{array}{l}\text { Strength Loss after Freezing to }-50 \\
\pm 5^{\circ} \mathrm{C} \text { and Thawing in } 5 \% \text { Sodium } \\
\text { Chloride Solution }(\%)\end{array}$} & \multicolumn{3}{|c|}{$\begin{array}{c}\text { Mass Loss after Freezing to }-50 \pm \\
5{ }^{\circ} \mathrm{C} \text { and Thawing in } 5 \% \text { Sodium } \\
\text { Chloride Solution (\%) }\end{array}$} & \multirow{2}{*}{$\begin{array}{c}\text { Assessment } \\
\text { of Frost } \\
\text { Resistance }\end{array}$} \\
\hline & & & 10 Cycles & 15 Cycles & 20 Cycles & 10 Cycles & 15 Cycles & 20 Cycles & \\
\hline 1 & -1 & -1 & 1.26 & 1.98 & 4.91 & 0.30 & 0.30 & 1.18 & F200 \\
\hline 2 & 0 & -1 & 1.58 & 2.74 & 5.93 & 0.30 & 1.57 & 1.87 & F150 \\
\hline 3 & +1 & -1 & 1.80 & 4.63 & 6.96 & 0.40 & 0.99 & 2.29 & F150 \\
\hline 4 & -1 & 0 & 1.16 & 1.85 & 4.78 & 0.31 & 0.48 & 1.12 & F200 \\
\hline 5 & 0 & 0 & 1.42 & 2.45 & 4.86 & 0.39 & 1.16 & 1.61 & F200 \\
\hline 6 & +1 & 0 & 2.16 & 3.80 & 4.88 & 0.20 & 0.79 & 1.79 & F200 \\
\hline 7 & -1 & +1 & 0.77 & 2.07 & 4.90 & 0.38 & 0.59 & 1.37 & F200 \\
\hline 8 & 0 & +1 & 0.87 & 3.33 & 4.88 & 0.39 & 0.78 & 1.36 & F200 \\
\hline 9 & +1 & +1 & 0.84 & 3.35 & 4.92 & 0.59 & 0.79 & 1.28 & F200 \\
\hline
\end{tabular}

In addition, one of the important indicators that determine the durability of the road surface concrete is wear resistance (abrasion). Repaired road sections are exposed to vehicle tires (i.e., abrasion) for a shorter time than the main pavement. However, it is also important for repair concretes to ensure sufficient wear resistance, in particular because, as shown in [43], this indicator affects the ability of the material to withstand complex frost-salt effects. At the same time, in [43], it is recommended to use concrete with abrasion no higher than $0.50 \mathrm{~g} / \mathrm{cm}^{2}$ in road construction. The abrasion resistance was determined on an abrasive wheel by DSTU B V.2.7-212:2009 [44], ASTM C944/C944M-19 [45]. The data of the abrasion resistance of the investigated concretes and fiber-reinforced concretes at nine control points of the experiment plan are shown in Table 5.

Table 5. Abrasion of the investigated concretes and fiber-reinforced concretes.

\begin{tabular}{cccccccccc}
\hline $\begin{array}{c}\text { No. of } \\
\text { Mixture }\end{array}$ & $\mathbf{1}$ & $\mathbf{2}$ & $\mathbf{3}$ & $\mathbf{4}$ & $\mathbf{5}$ & $\mathbf{6}$ & $\mathbf{7}$ & $\mathbf{8}$ & $\mathbf{9}$ \\
\hline $\begin{array}{c}\text { Abrasion } \\
\left(\mathrm{g} / \mathrm{cm}^{2}\right)\end{array}$ & 0.30 & 0.32 & 0.34 & 0.22 & 0.24 & 0.26 & 0.20 & 0.24 & 0.25 \\
\hline
\end{tabular}


According to the data given in Table 5, an ES-model was built (6) reflecting the effect of the hardening accelerator and steel anchor fiber amount on the abrasion resistance of the investigated concretes and fiber-reinforced concretes. For the ES-model (6), the experimental error is $0.0038 \mathrm{~g} / \mathrm{cm}^{2}$ :

$$
G\left(\mathrm{~g} / \mathrm{cm}^{2}\right)=0.243+0.022 x_{1}-0.005 x_{1}^{2}+0.002 x_{1} x_{2}-0.045 x_{2}+0.035 x_{2}^{2},
$$

Figure 7 shows the diagram drawn according to the ES-model (6).

The diagram data reflect that steel fiber reinforcement reduces the concrete abrasion resistance by $30-35 \%$ to values within 0.2 to $0.24 \mathrm{~g} / \mathrm{cm}^{2}$. Compositions with the maximum amount of hardening accelerator without steel fiber also have a rather low abrasion rate, which will have a positive effect on the repair concrete durability.

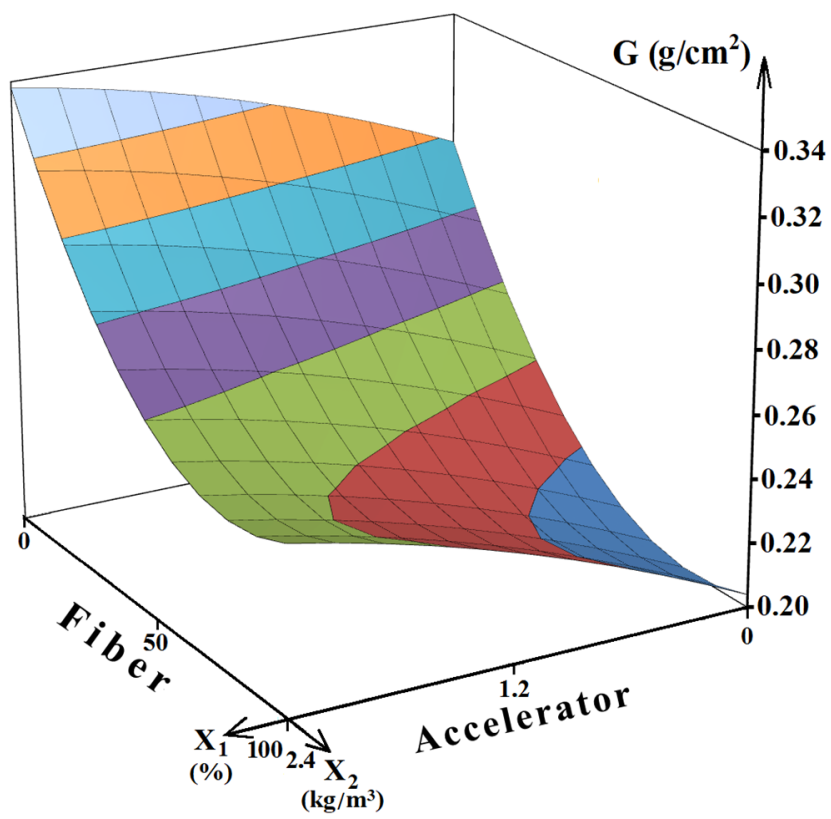

Figure 7. Influence of varied factors on concrete and fiber-reinforced concrete abrasion resistance.

For repair materials, shrinkage is an important quality indicator, since it is through shrinkage deformations that its adhesion to the existing cement-concrete coating can be broken down. It is known [46] that the most important structural indicator for minimizing concrete shrinkage is the $W / C$ mixture. As noted above, all concretes studied at this stage were modified with a rational amount of MasterGlenium SKY 608 polycarboxylate superplasticizer $(1.2 \%)$, which ensured the minimum $W / C$ ratio.

The shrinkage of concrete during hardening in air-dry conditions was determined as follows. Concrete prisms of $10 \mathrm{~cm} \times 10 \mathrm{~cm} \times 40 \mathrm{~cm}$ for the first day after molding were stored in molds in a humidity chamber. After that, the prisms were dismantled and placed in air-dry conditions (humidity $60 \pm 5 \%$, temperature $20 \pm 2{ }^{\circ} \mathrm{C}$ according to DSTU V.2.7-216:2009 [47]). With the dial indicators, fixed on tripods, the shrinkage of the samples after $3 \mathrm{~h}, 6 \mathrm{~h}$ and 1, 2, 3 and 7 days of being in air-dry conditions was determined. The data of the concrete and fiber-reinforced concrete shrinkage ratios of various compositions are shown in Table 6.

According to the data given in Table 6, graphs are built (Figure 8) reflecting the effect of the fiber amount on the concrete shrinkage with a different amount of the hardening accelerator Sika Rapid 3 in the composition. 
Table 6. Shrinkage ratios of concrete and fiber-reinforced concrete in air-dry conditions.

\begin{tabular}{ccccccc}
\hline \multirow{2}{*}{$\begin{array}{c}\text { No. of Mixture } \\
\text { (Table } \mathbf{1 )}\end{array}$} & $\mathbf{3 ~ h}$ & $\mathbf{6 ~ h}$ & $\mathbf{1}$ Day & 2 Days & 3 Days & 7 Days \\
\cline { 2 - 7 } & 0.609 & 0.865 & 1.218 & 1.376 & 1.445 & 1.604 \\
1 & 0.653 & 0.890 & 1.221 & 1.342 & 1.383 & 1.507 \\
2 & 0.725 & 0.942 & 1.21 & 1.312 & 1.365 & 1.465 \\
3 & 0.565 & 0.748 & 1.07 & 1.211 & 1.275 & 1.353 \\
4 & 0.564 & 0.718 & 1.035 & 1.163 & 1.225 & 1.325 \\
5 & 0.660 & 0.820 & 1.082 & 1.203 & 1.214 & 1.337 \\
6 & 0.505 & 0.733 & 1.035 & 1.179 & 1.235 & 1.340 \\
7 & 0.528 & 0.75 & 1.031 & 1.153 & 1.212 & 1.304 \\
8 & 0.668 & 0.827 & 1.075 & 1.195 & 1.215 & 1.311 \\
9 & & & & & &
\end{tabular}
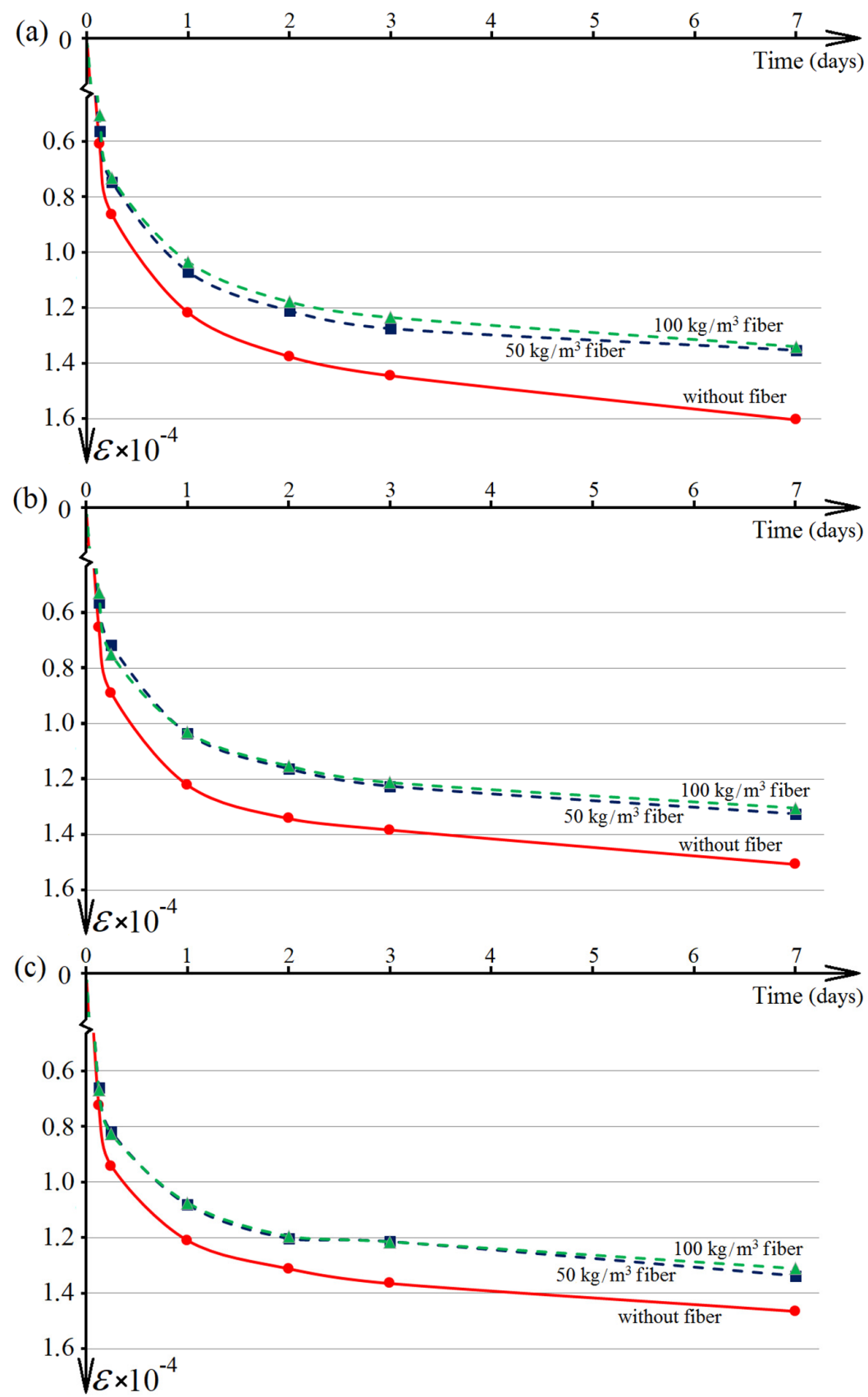

Figure 8. Shrinkage ratio of investigated fiber-concretes (Table 6) during hardening in air-dry conditions: (a) mixtures No. 1, No. 4, No. 7; (b) mixtures No. 2, No. 5, No. 8; (c) mixtures No. 3, No. 6, No. 9. 
After 7 days of hardening, concrete shrinkage does not stop, but the general nature of the change in shrinkage decreases, which confirms the positive influence of variable factors on this characteristic.

Regardless of the hardening accelerator amount, fiber-reinforced concretes, with a fiber amount of $50 \mathrm{~kg} / \mathrm{m}^{3}$ and with a fiber amount of $100 \mathrm{~kg} / \mathrm{m}^{3}$, are characterized by significantly less shrinkage compared to unreinforced ones. This is explained by the ability of the fiber framework to keep the structural blocks of the composite from moving when moisture is lost during structure formation [48,49].

The fact that compositions with fiber amounts of $50 \mathrm{~kg} / \mathrm{m}^{3}$ and $100 \mathrm{~kg} / \mathrm{m}^{3}$ are characterized by almost the same shrinkage can be explained by the fact that with an increase in the amount of dispersed reinforcement amount in the composition, the $W / C$ mixture increases. Accordingly, the positive influence of the spatial grid of the fiber reinforcement is leveled by the influence of an increased water amount in the concrete mixture.

The hardening accelerator amount also affects the shrinkage value of the investigated concretes, but less significantly. Due to the addition of the maximum dosage of Sika Rapid 3, the concrete shrinkage at the age of 7 days is reduced by $3.9 \%$ and with the addition of $1.2 \%$ of this modifier-by $2.7 \%$. Shrinkage reducing due to the use of a hardening accelerator is explained by the internal stresses in the composite material, arising in the process of structure formation and moisture loss, being restrained by a cement-sand matrix, which is more durable in the early stages of hardening.

\section{Conclusions}

The effect of the hardening accelerator and steel anchor fiber on the strength properties, frost resistance, abrasion resistance and shrinkage during the hardening of steel-fiberreinforced concrete for rigid highway and airfield pavement repair has been studied. It was found that by using inexpensive cement CEM II/ AS 42.5 and row aggregates due to the use of a rational amount of accelerator (from 1 to $2 \%$ of the cement content, $4-8 \mathrm{~kg} / \mathrm{m}^{3}$ ) and steel anchor fiber (from $60-90 \mathrm{~kg} / \mathrm{m}^{3}$ ), it is possible to obtain a highly efficient material for full depth repair technology. The resulting fiber-reinforced concrete compositions already at the age of 2 days have a compressive strength of at least $55 \mathrm{MPa}$ and a flexural strength of at least $8.5 \mathrm{MPa}$. The durability of the repair concrete and fiber-reinforced concrete is ensured by high frost resistance (F200) and low abrasion resistance $\left(<0.24 \mathrm{~g} / \mathrm{cm}^{2}\right)$. Due to the reduced shrinkage, these concretes provide good performance in the structure of the rigid pavement that is being repaired.

Further research requires the study of the orientation of steel fibers in the cross-section of the repair section, which can significantly increase the flexural strength. Additional studies can focus on the effect of a hardening accelerator on the dynamics of strength gain at negative temperatures in combination with dispersed steel fiber reinforcement.

Author Contributions: Conceptualization, Ž.K. and S.K.; methodology, V.K., I.G. and S.K.; validation, Ž.K., V.K. and S.K.; formal analysis, Ž.K. and S.K.; resources, V.K. and I.G.; data curation, Ž.K. and S.K.; writing-original draft preparation, Ž.K. and V.K.; writing-review and editing, S.K. and I.G.; visualization, S.K., S.K. and V.K.; supervision, Ž.K. and I.G.; project administration, Ž.K. and V.K.; funding acquisition, Ž.K. All authors have read and agreed to the published version of the manuscript.

Funding: This research received no external funding.

Institutional Review Board Statement: Not applicable.

Informed Consent Statement: Not applicable.

Data Availability Statement: Not applicable.

Conflicts of Interest: The authors declare no conflict of interest. 


\section{References}

1. Laszlo, G.; Zsolt, B. Long-life pavements-European and American perspectives NBM\&CW. Neww Build. Mater. Constr. World 2018, $24,122-135$.

2. AC No:150/5320-6G_Airport Pavement Design and Evaluation. Available online: https://www.faa.gov/regulations_policies/ advisory_circulars/index.cfm/go/document.information/documentID/1039843 (accessed on 19 December 2021).

3. Pavement Quality Concrete for Airfields, Specification 033; Her Majesty Stationary Office: Richmond, UK, February 2017; 72p.

4. Zhao, Z.; Ma, Q.; Xu, Q.; Sun, F. A review: Fast repair technology of cement concrete pavement. E3S Web Conf. $2019,136,04053$.

5. Karmacharya, A.; Chao, S.-H. Precast ultra-high-performance fiber-reinforced concrete for fast and sustainable pavement repair MATEC Web Conf. 2019, 271, 01004. [CrossRef]

6. Porras, Y.A. Durable High Early Strength Concrete. Master's Thesis, Kansas State University, Manhattan, KS, USA, 2018.

7. Van Dam, T.J.; Peterson, K.R.; Sutter, L.L.; Panguluri, A.; Sytsma, J. Portland Cement Concrete for Pavement Rehabilitation; Final Report for Early-Opening-to-Traffice; Transportation Research Board of the National Academies: Washington, DC, USA, 2005.

8. Dvorkin, L.Y.; Bordyuzhenko, O.M. Technological properties of high-strength fibroconcretes with plasticizers of different types. Sci. Constr. 2018, 2, 10-17.

9. Sanitsky, M.A.; Marushchak, U.D.; Kirakevich, I.I.; Mazurak, T.A. Especially Fast-Hardening Compositions for High-Performance Concretes; Bulletin of Lviv Polytechnic National University; Theory and Practice of Construction: Lviv, Ukraine, 2013; № 755; pp. 385-390.

10. Dvorkin, L.Y.; Babych, E.M.; Zhitkovsky, V.V.; Bordyuzhenko, O.M. High-Strength, Fast-Hardening Concretes and Fibrous Concretes; NUVGP: Rivne, Ukraine, 2017.

11. Yu, R.; Spiesz, P.; Brouwers, H.J.H. Dynamic performance of a sustainable ultra-high performance fibre reinforced concrete under high velocity projectile impact. In Tagungsbericht/IBAUSIL, 19. Internationale Baustofftagung; Fischer, H.-B., Ed.; Finger-Institut für Baustoffkunde: Weimar, Germany, 2015; Volume 16, pp. 1-1215-1-1222.

12. Yu, B.; Chen, Y.; Wang, H.; Li, X.; Xie, C.; Li, S. Experiment on control measures of shrinkage and cracking of high strength manufactured sand concrete containing a large amount of high absorbency stone powder. Fuhe Cailiao Xuebao/Acta Mater. Compos. Sin. 2021, 38, 2737-2746.

13. Harrington, D.; Fick, G.; Taylor, P. Preservation and Rehabilitation of Urban Concrete Pavements Using Thin Concrete Overlays: Solutions for Joint Deterioration in Cold Weather States; National Concrete Pavement Technology Center: Ames, IA, USA, 2014.

14. Kabashi, N.; Krasniqi, C.; Hadri, R.; Sadikah, A. Effect of fibre reinforced concrete and behavior in rigid pavements. Int. J. Struct. Civ. Eng. Res. 2018, 7, 29-33. [CrossRef]

15. Jonbi, J.; Tjahjani, A.R.; Tinumbia, N.; Pattinaja, A.M.; Haryono, B.S. Repair of rigid pavement using micro concrete material. MATEC Web Conf. 2018, 195, 01014. [CrossRef]

16. Kianets, A.V. Investigation of Steel Fiber Concrete Abrasion. In Bulletin of SUSU. Series Construction and Architecture; South Ural State University: Southern Ural, Russia, 2018; Volume 18, pp. 53-57.

17. Babych, E.M.; Andriychuk, O.V.; Uzhegov, S.O.; Shapoval, I.V. Application of steel fiber concrete in road construction. Mod. Technol. Methods Calc. Constr. 2015, 4, 3-9.

18. Hossain, M.S.; Han, S.; Kim, S.K.; Yun, K. Long-term effect of accelerator content on flexural toughness of steel fiber reinforced shotcrete for tunnel construction. Case Stud. Constr. Mater. 2021, 15, e00706. [CrossRef]

19. Ghosh, D.; Abd-Elssamd, A.; John Ma, Z.; Hun, D. Development of high-early-strength fiber-reinforced self-compacting concrete. Constr. Build. Mater. 2021, 266, 121051. [CrossRef]

20. Choi, W.-C.; Jung, K.-Y.; Jang, S.-J.; Yun, H.-D. The influence of steel fiber tensile strengths and aspect ratios on the fracture properties of high-strength concrete. Materials 2019, 12, 2105. [CrossRef] [PubMed]

21. Song, H.; Zhenq, T. Mechanical properties of steel fibre-reinforced high strength concrete with high early-age strength used in freezing shaft lining. Appl. Mech. Mater. 2012, 174-177, 1388-1393. [CrossRef]

22. Bandelj, B.; Saje, D.; Sustersic, J.; Lopatic, J.; Saje, F. Free shrinkage of high performance steel fibre reinforced concrete. J. Test. Eval. 2011, 39, 166-176.

23. Kim, D.-J.; Kim, S.-H.; Choi, W.-C. Characteristics of restrained drying shrinkage on arched steel fiber-reinforced concrete. Appl. Sci. 2021, 11, 7537. [CrossRef]

24. Lau, C.K.; Chegenizadeh, A.; Htut, T.N.S.; Nikraz, H. Performance of the steel fibre reinforced rigid concrete pavement in fatigue. Buildings 2020, 10, 186. [CrossRef]

25. Biswas, R.K.; Bin Ahmed, F.; Haque, M.E.; Provasha, A.A.; Hasan, Z.; Hayat, F.; Sen, D. Effects of steel fiber percentage and aspect ratios on fresh and harden properties of ultra-high performance fiber reinforced concrete. Appl. Mech. 2021, 2, 501-515. [CrossRef]

26. Zhang, P.; Li, Q.; Chen, Y.; Shi, Y.; Ling, Y.-F. Durability of steel fiber-reinforced concrete containing $\mathrm{SiO}_{2}$ nano-particles. Materials 2019, 12, 2184. [CrossRef]

27. DSTU B V.2.7-75-98. Crushed Stone and Gravel Are Dense Natural for Building Materials, Products, Structures and Works. Specifications. Available online: http:/ / online.budstandart.com/ru/catalog/doc-page?id_doc=4674 (accessed on 19 December 2021).

28. DSTU B V.2.7-32-95. Building Materials. Sand Dense Natural for Construction Materials, Products, Designs and Works. Specifications. Available online: http:/ / online.budstandart.com/ru/catalog/doc-page?id_doc=4053 (accessed on 19 December 2021).

29. BS EN 12620:2013; Aggregates for Concrete. British Standard Institution: London, UK, 2013.

30. ASTM C 33/C33M-18; Standard Specifications for Concrete Aggregates. ASTM International: West Conshohocken, PA, USA, 2018. 
31. Kryzhanovskyi, V.; Kroviakov, S.; Zavoloka, M. High-early strength concretes modified with polycarboxylate admixture on different cement types. IOP Conf. Ser. Mater. Sci. Eng. 2021, 1141, 012003. [CrossRef]

32. Kryzhanovskyi, V.O.; Kroviakov, S.O.; Zavoloka, M.V. Influence of metakaolin on properties of concrete modified with polycarboxylate admixture for rigid pavement repair. Bull. Odessa State Acad. Civ. Eng. Archit. 2021, 82, 90-97. [CrossRef]

33. Lyashenko, T.V.; Voznesensky, V.A. Methodology of Recipe-Technological Fields in Computer Building Materials Science; Astroprint: Odessa, Ukraine, 2017.

34. Kryzhanovskiy, V.; Kroviakov, S. Strength of rigid pavement concretes modified with polycarboxylate admixture on different types of cement. Bull. Odessa State Acad. Civ. Eng. Archit. 2020, 79, 92-98. [CrossRef]

35. BS EN 12350-2:2019; Testing Fresh Concrete. Slump Test. British Standard Institution: London, UK, 2019.

36. ASTM C78/C78M-16; Standard Test Method for Flexural Strength of Concrete (Using Simple Beam with Third-Point Loading). ASTM International: West Conshohocken, PA, USA, 2016.

37. DSTU B V.2.7-214:2009. Building Materials. Concrete. Methods for Determining the Strength of Control Samples. Available online: http:/ / online.budstandart.com/ua/catalog/doc-page.html?id_doc=25943 (accessed on 19 December 2021).

38. BS EN 12390-5:2009; Testing Hardened Concrete. Flexural Strength of Test Specimens. British Standard Institution: London, UK, 2009.

39. BS EN 12390-3:2009; Testing Hardened Concrete. Compressive Strength of Test Specimens. British Standard Institution: London, UK, 2009.

40. Pukharenko, Y.V.; Panteleev, D.A.; Zhavoronkov, M.I. Determination of the fiber contribution to the formation of the strength of steel fiber reinforced concrete. Bull. Civ. Eng. 2017, 1, 172-176.

41. Brykov, A.S. Hydration of Portlandcement. Saint Petersburg State Institute of Technology: Saint-Petersburg, Russia, 2008.

42. DSTU B V.2.7-49-96. Concrete. Accelerated Methods for Determining Frost Resistance during Repeated Freezing and Thawing. Available online: http:/ / online.budstandart.com/ru/catalog/doc-page?id_doc=4950 (accessed on 19 December 2021).

43. Tolmachev, S.N.; Kondratyeva, I.G.; Chuguenko, A.N.; Grinchenko, R.O. The Relationship between Abrasion and Frost Resistance of Road Concrete. Bulletin of the Kharkiv National Automobile and Highway University; Kharkiv National Automobile and Highway University: Kharkiv, Ukraine, 2005; № 30; pp. 52-55.

44. DSTU B V.2.7-212:2009. Building Materials. Concrete. Methods for Determining Abrasion Resistance. Available online: http: / / online.budstandart.com/ru/catalog/doc-page?id_doc=25953 (accessed on 19 December 2021).

45. ASTM C944/C944M-19; Standard Test Method for Abrasion Resistance of Concrete or Mortar Surfaces by the Rotating Cutter Method. ASTM International: West Conshohocken, PA, USA, 2019.

46. Kalinovskaya, N.N.; Kotov, D.S.; Ivanova, E.A. Durability of concrete. Analysis of the causes and methods of reducing the shrinkage deformations of the modified concrete. Concr. Technol. 2017, 11-12, 14-17.

47. DSTU V.2.7-216:2009. Building Materials. Concrete. Methods for Determining Shrinkage and Creep Strains. Available online: http: / / online.budstandart.com/ru/catalog/doc-page?id_doc=25914 (accessed on 19 December 2021).

48. Dvorkin, L.Y.; Mishutin, A.V.; Krovyakov, S.O.; Bordyuzhenko, O.M.; Kinta, L. Effective Types of Concrete; Odessa State Academy of Civil Engineering and Architecture: Odessa, Ukraine, 2021.

49. Afroughsabet, V.; Biolzi, L.; Ozbakkaloglu, T. High-performance fiber-reinforced concrete: A review. J. Mater. Sci. 2016, 51, 6517-6551. [CrossRef] 